\title{
A new species of Phrixotrichus (Araneae, Theraphosidae) from southwestern Argentina and new distributional data for $P$. vulpinus
}

\author{
Nelson Ferretti
}

Centro de Estudios Parasitológicos y de Vectores CEPAVE (CCT- CONICET- La Plata) (UNLP), Boulevard 120 s/n e/ 61 y 62, La Plata, Argentina. (nferretti@conicet.gov.ar)

\begin{abstract}
A new species of Phrixotrichus Simon, 1889, P. pucara sp. nov., is described and illustrated based on a male from Pucará river, Neuquén province, Argentina. Male can be distinguished from all other species of the genus by the presence of a long strong spine on inner face of prolateral branch of tibial apophysis; also, it differs from P. scrofa (Molina, 1788) and P. vulpinus (Karsch, 1880) by a serrated prolateral keel of the male palpal bulb. Male resembles $P$. jara Perafán \& Pérez-Miles, 2014 but can be distinguished by the uniform color on dorsal cephalothorax and by the palpal organ morphology being wider on the bulb base and embolus shorter and thicker, with the tip of embolus not so directed retrolaterally and prolateral keel bearing a serrated edge with three teeth. Additionally, $P$. vulpinus is reported for the first time for Argentina along with new distributional data.
\end{abstract}

KEYWORDS. Taxonomy, spiders, tarantula, Theraphosinae.

\begin{abstract}
RESUMEN. Una nueva especie de Phrixotrichus (Araneae, Theraphosidae) del sudoeste de Argentina y nuevos datos de distribución para P. vulpinus. Se describe e ilustra una nueva especie de Phrixotrichus Simon, 1889, P. pucara sp. nov., basada en un macho del río Pucará, provincia de Neuquén, Argentina. El macho se distingue de las especies restantes del género por la presencia de una espina larga y fuerte en la cara interna de la rama prolateral de la apófisis tibial; además, difiere de $P$. scrofa (Molina, 1788) y $P$. vulpinus (Karsch, 1880) por una quilla prolateral aserrada en el bulbo del macho. El macho recuerda a P. jara Perafán \& Pérez-Miles, 2014 pero se distingue por el color uniforme en el dorso del caparazón y por la morfología del órgano palpar siendo la base del bulbo más ancha y el émbolo más corto y grueso, con el extremo del émbolo dirigido no tan retrolateralmente y la quilla prolateral lleva un borde aserrado con tres dientes. Adicionalmente, se reporta por primera vez para Argentina la presencia de $P$. vulpinus junto con nuevos datos en su distribución.
\end{abstract}

PALABRAS-CLAVE. Taxonomía, arañas, tarantula, Theraphosinae.

Phrixotrichus is a Neotropical genus of Theraphosinae that has been suffered many complicated synonymies over the years (BONNET, 1958; PÉREZ-Miles et $a l ., 1996)$. This genus of tarantulas was based on specimens collected near Santiago de Chile (Chile) and originally named as Aranea scrofa (Molina, 1788). Later, PORTER (1930) transferred Aranea scrofa to Phrixotrichus Simon, 1889. Schiapelli \& Gerschman de Pikelin (1963) and LEGENDRE \& CALDERÓN-GoNZÁLEZ (1984) provided full descriptions of male and female of P. scrofa. PÉreZMiLes et al. (1996) removed Phrixotrichus scrofa and placed in Paraphysa Simon, 1892 based on the reduced labial cuspules, the bulb morphology and the absence of stridulatory setae. In the same contribution Phrixotrichus was established as a senior synonym of Grammostola Simon, 1892. Afterward, SchmidT (1996a) removed Phrixotrichus from the synonymy of Grammostola and considered Phrixotrichus as a synonym of Euathlus Ausserer, 1875 (SchmidT, 1996b).

Recently, based on a phylogenetic analysis of morphological characters of specimens from Chile, the species composition of Euathlus, Paraphysa and Phrixotrichus was revised by Perafán \& Pérez-Miles (2014). As a consequence, authors revalidate the genus Phrixotrichus, as well as a new composition of species that now includes: Phrixotrichus jara Perafán \& PérezMiles, 2014; Phrixotrichus scrofa (Molina, 1788) and Phrixotrichus vulpinus (Karsch, 1880). Consequently, the genus Phrixotrichus is diagnosed by the presence of urticating setae Type IV gathered on two lateral patches; male is characterized by the palpal bulb morphology with two subequal prolateral keels and the tip directed retrolaterally, tibial apophysis with only one apical spine on retrolateral branch and absence of basal spine on prolateral branch; female is distinguished by the presence of two spermathecal receptacles with a lateral spheroid chamber.

During a study of some specimens from the arachnological collection of the "Museo Argentino de Ciencias Naturales Bernardino Rivadavia" (MACN-Ar), Buenos Aires, Argentina, from the Andean chain and foothills of Neuquén province, a single male of a new species of Phrixotrichus was discovered and is here described, diagnosed and figured. Additionally, based on the revision of specimens from Argentina misidentified as Phrixotrichus scrofa by Schiapelli \& Gerschman de Pikelin (1963), I provided the first record of Phrixotrichus vulpinus (Karsch, 1880) for Argentina and new distributional data.

\section{MATERIAL AND METHODS}

The following abbreviations are utilized: ALE, anterior lateral eyes; AME, anterior median eyes; D, dorsal; P, prolateral; PI, prolateral inferior keel; PB, prolateral branch of tibial apophysis; PS, prolateral superior keel; PLE, posterior lateral eyes; PLS, posterior lateral spinnerets; PME, posterior median eyes; PMS, posterior 
median spinnerets; R, retrolateral; RB, retrolateral branch of tibial apophysis. All measurements are given in millimeters and were made with digital dial calipers with an error of $0.01 \mathrm{~mm}$, rounded up to one significant decimal where appropriate and an Olympus stereoscopic microscope equipped with a calibrated ocular micrometer scale. Appendage measurements were based on left appendages in the dorsal view. Lengths of leg articles were taken from the mid-proximal point of articulation to the mid-distal point of the article (sensu CoYLE, 1995, fig. 1 and Bond, 2012, figs 11-16). Photographs of preserved material were taken with a SONY Hx200v. The material studied is deposited in the Museo Argentino de Ciencias Naturales "Bernardino Rivadavia" (MACN-Ar), Buenos Aires, Argentina. Spine notation follows Petrunkevitch (1925). The abdominal urticating setae were removed from the dorsal area by pincette, placed in alcohol and examined under a Nikon Eclipse 600 microscope. The terminology of urticating setae follows CoOKe et al. (1972). Male palpal bulb keel terminology follows BERTANI (2000).

\section{RESULTS AND DISCUSSION}

\section{Prhixotrichus Simon, 1889}

Phrixotrichus Simon, 1889: Orthotrichus KaRsCH, 1880:390 (preoccupied); Ashantia STRAND 1908:770.

Type species: Phrixotrichus scrofa (Molina, 1788).

Other material examined. Phrixotrichus jara Perafán \& Pérez-Miles (2014), ô, Chile, Peulla, XI.1952, Gliesch leg. (MACN-Ar 3685).

Modified diagnosis. Males differ from other Theraphosinae genera by the presence of urticating setae type IV on two lateral patches. Male palpal bulb with two subequal prolateral keels (PS and PI), PI serrated in P. jara and P. pucara sp. nov., and the tip directed retrolaterally. Tibial apophysis with only one apical spine on RB, PB without spines or with a long spine on P. pucara sp. nov. Females differ by the presence of two spermathecal receptacles with a lateral spheroid chamber.

\section{Phrixotrichus pucara sp. nov.}

$$
\text { (Figs 1-7; Tab. I) }
$$

Type material. Holotype $\widehat{\partial}$, Argentina, Neuquén, Department of San Martín de los Andes, next to Pucará river, II.1951, J. Navas leg. (MACN-Ar 5615).

Etymology. The specific epithet refers to the type locality and means fortress spelling in "quechua" (original language from the people of the Andes). Also, Pucará is a twin turboprop airplane manufactured in Argentina that flight for the first time on August 20, 1969 and was used actively during the Malvinas war (1982) by the Argentinean Air Force.

Diagnosis. Male of P. pucara sp. nov. differs from

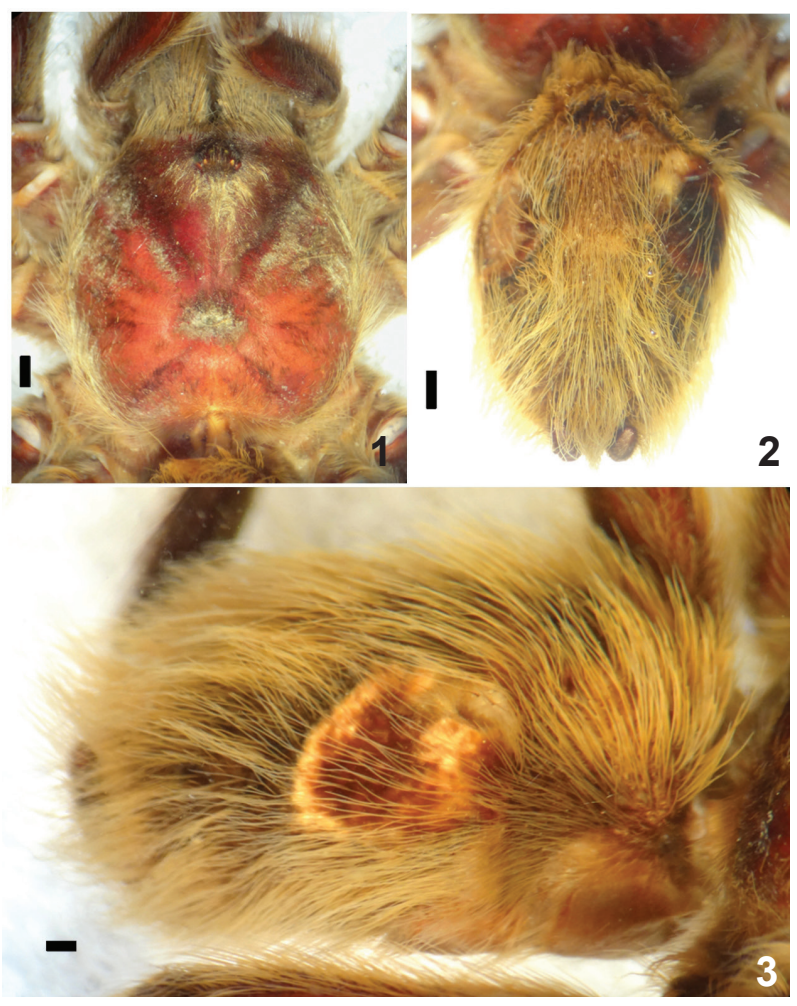

Figs. 1-3. Phrixotrichus pucara sp. nov., holotype $\widehat{\jmath}$ (MACN-Ar 5615): 1, carapace, dorsal view; 2 , abdomen, dorsal view; 3 , abdomen, lateral view showing urticating patches. Scales: $1 \mathrm{~mm}$.

those of all other species of the genus by the presence of a long strong spine on inner face of $\mathrm{PB}$ of tibial apophysis (Fig. 4); also, it differs from P. scrofa and P. vulpinus by the palpal organ morphology with serrated PI (Figs 5, 6). Male resembles $P$. jara but can be distinguished by the uniform color on dorsal cephalothorax (Fig. 1) and by the palpal organ morphology being wider on the bulb base and embolus shorter and thicker, with the tip not so directed retrolaterally and PI has a serrated edge with 3 teeth (Fig. 7).

Description. Male holotype. Color in alcohol: carapace light brown bearing long golden setae (Fig. 1), also on dorsal chelicerae and coxa, trochanter and femur of legs. Abdomen black with golden setae and two lateral patches of urticating setae (Figs 2, 3). Total length (not including chelicerae or spinnerets) 23.9. Cephalothorax 11.5 long, 10.9 wide. Abdomen 13.1 long, 8.4 wide. Urticating setae type III and IV present. Spinnerets: PMS, 1.2 long; PLS, 1.3 basal, 1.1 middle, 1.7 distal. Eyes: tubercle length 1.2, width 1.5. Clypeus narrow, 0.2. Anterior eyes row procurved, posterior row recurved. Eyes sizes and interdistances: AME 0.22, ALE 0.28, PME 0.20, PLE 0.25, AME - AME 0.29, AME - ALE 0.17, PME - PME 0.71, PME - PLE 0.12, ALE - PLE 0.33. Fovea transverse, procurved, 1.6 wide. Labium length 0.8 , width 1.8 , with 17 cuspules. Maxillae each with $c a .85$ cuspules spread over internal face. Sternum: length 4.1, width 3.8. Chelicerae with 7 large teeth on promargin, group of 5 smaller basal teeth behind promarginal line. Length of legs and palpal segments in Tab I. Tarsi I - IV densely scopulate and 

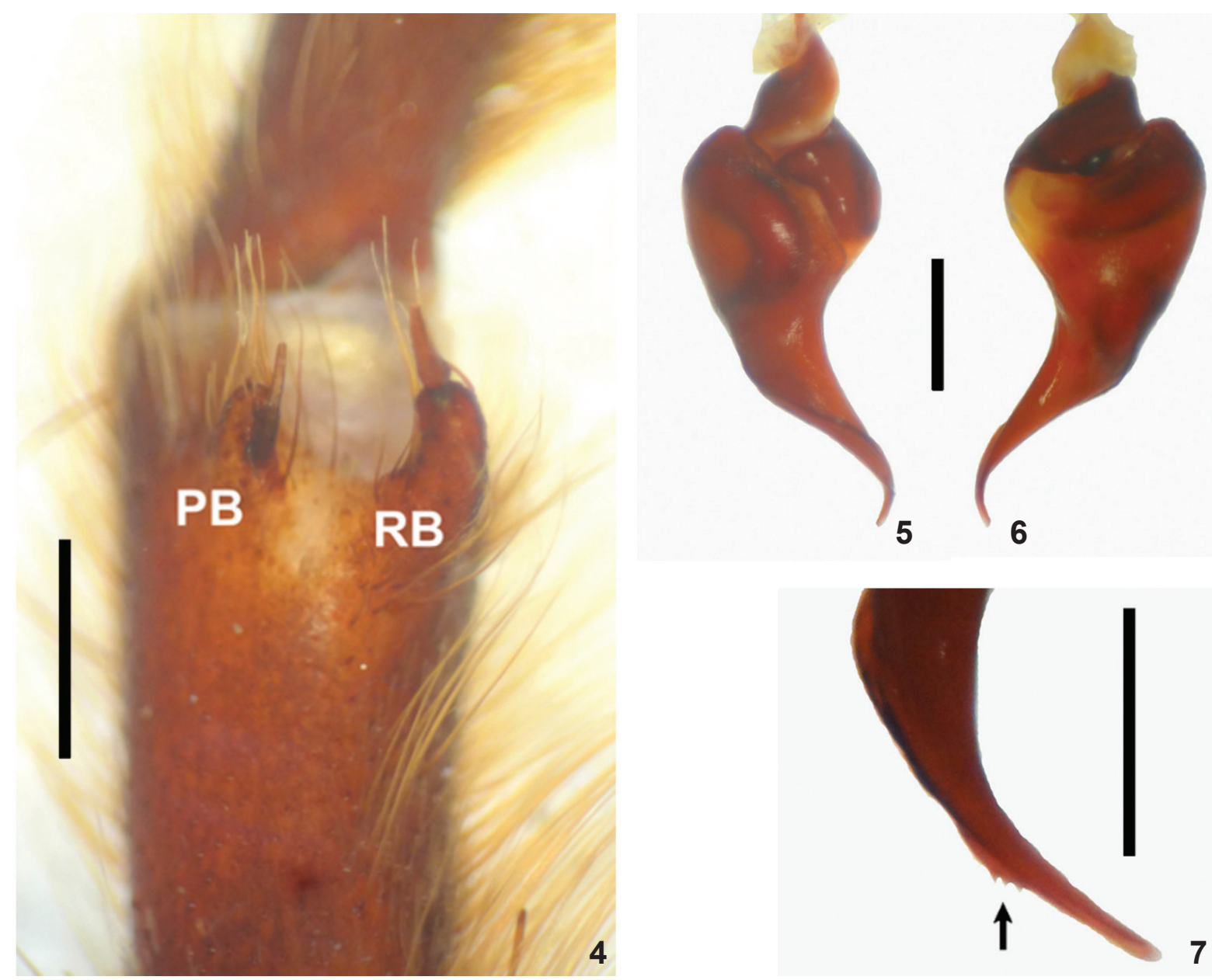

Figs. 4-7. Phrixotrichus pucara sp. nov., holotype ô (MACN-Ar 5615): 4, tibial apophysis, ventral view. Palp: 5, prolateral view; 6, retrolateral view; 7, close to embolus showing the serrated keel with three teeth (arrow) (PB, prolateral branch; RB, retrolateral branch). Scales: $1 \mathrm{~mm}$.

Tab. I. Phrixotrichus pucara sp. nov., length of leg and palpal segments of male.

\begin{tabular}{lccccc}
\hline & I & II & III & IV & Palp \\
\hline Femur & 9.9 & 9.6 & 9.1 & 9.0 & 6.7 \\
Patella & 4.9 & 4.7 & 4.4 & 4.5 & 3.5 \\
Tibia & 9.7 & 7.1 & 5.8 & 7.0 & 4.4 \\
Metatarsus & 7.1 & 6.3 & 4.0 & 9.0 & - \\
Tarsus & 5.6 & 5.1 & 31.2 & 4.4 & 1.7 \\
Total & 37.2 & 32.8 & 33.9 & 16.3 \\
\hline
\end{tabular}

complete. Metatarsi I 2/3 scopulate, II 1/2 apical scopulate, III 1/3 apical scopulate, IV $1 / 4$ apical scopulate. Spination: femora, patellae and tarsi of palp and legs I - IV 0. Tibiae: palp 0; I 0; II 2 P; III 1 P; IV 1 - 2 V. Metatarsi: I 11 - 1 V; II $1-1 \mathrm{~V}$; III $1-1-1 \mathrm{~V}, 1-1 \mathrm{P}, 1 \mathrm{R} ;$ IV $2-2 \mathrm{~V}, 1 \mathrm{P}$, $1-1-2 \mathrm{R}$. Tibia I with ventral apophysis formed by two branches: prolateral smaller, with a basal long megaspine on inner face; retrolateral larger with one apical shorter spine (Fig. 4). Flexion of metatarsus I on retrolateral side of tibial apophysis. Palpal bulb piriform with two subequal prolateral keels (PS and PI) (Figs 5, 6); PI has a serrated edge with three teeth (Fig. 7).

Female unknown.

Distribution. Known only from the type locality (Fig. 11).

\section{Phrixotrichus vulpinus (Karsch, 1880)}

(Figs 8-10)

Diagnosis. Male resembles P. scrofa but differs in having more separated prolateral keels of palpal bulb and by the embolus less slender (Figs 8,9). Female differs by the presence of a digitiform projection on one or both seminal receptacles, and the lateral spheroid chamber of seminal receptacles with large lobes (Fig. 10).

Additional material examined. ô, Argentina, Neuquén, Department of San Martín de los Andes, HuaHum, II.1961, M. Galiano leg. (MACN-Ar 5616); đิ, Argentina, Neuquén, Nahuel Huapi, 1967, Havrylenko leg. (MACN-Ar 5614); 20̂, q, Argentina, Neuquén, Department 


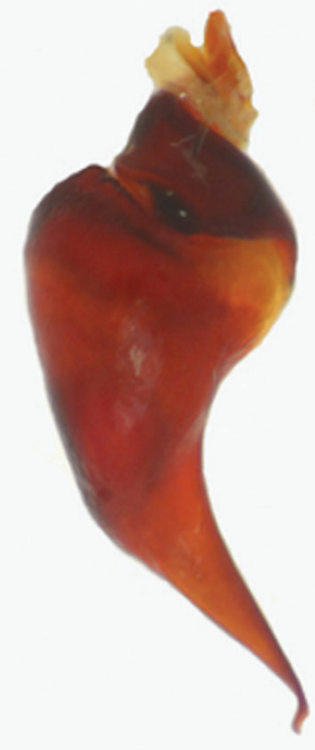

8

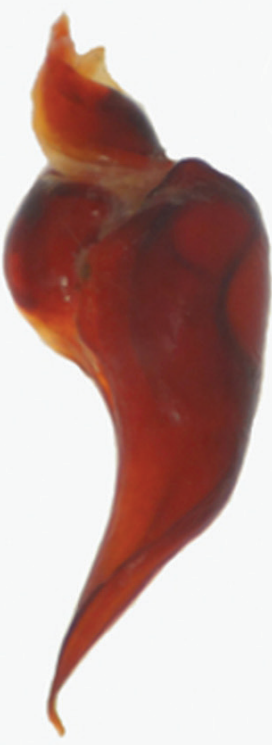

9

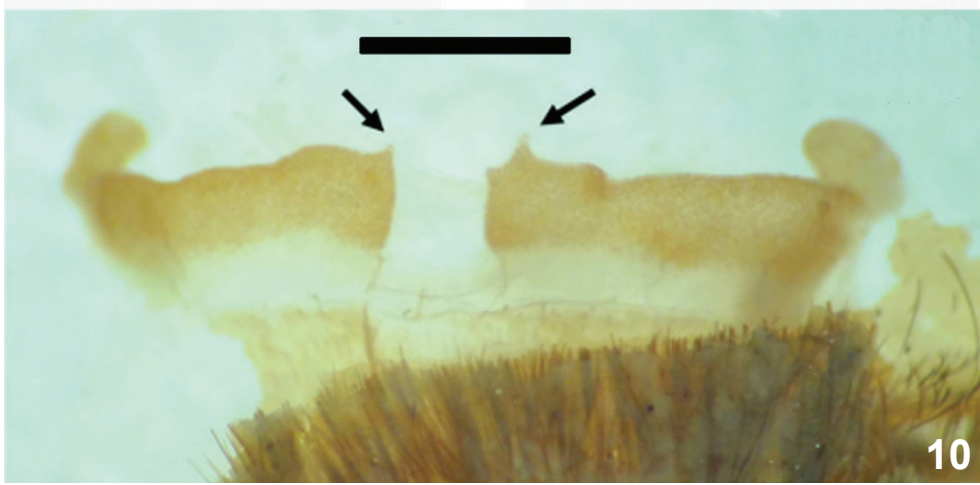

Figs. 8-10. Phrixotrichus vulpinus (Karsch, 1888), male (MACN-Ar 5617). Palp: 8, prolateral view; 9, retrolateral view. Female (MACN-Ar 5617): 10 , spermathecae, dorsal view, the arrow shows digitiform projection on seminal receptacles. Scales: $1 \mathrm{~mm}$.

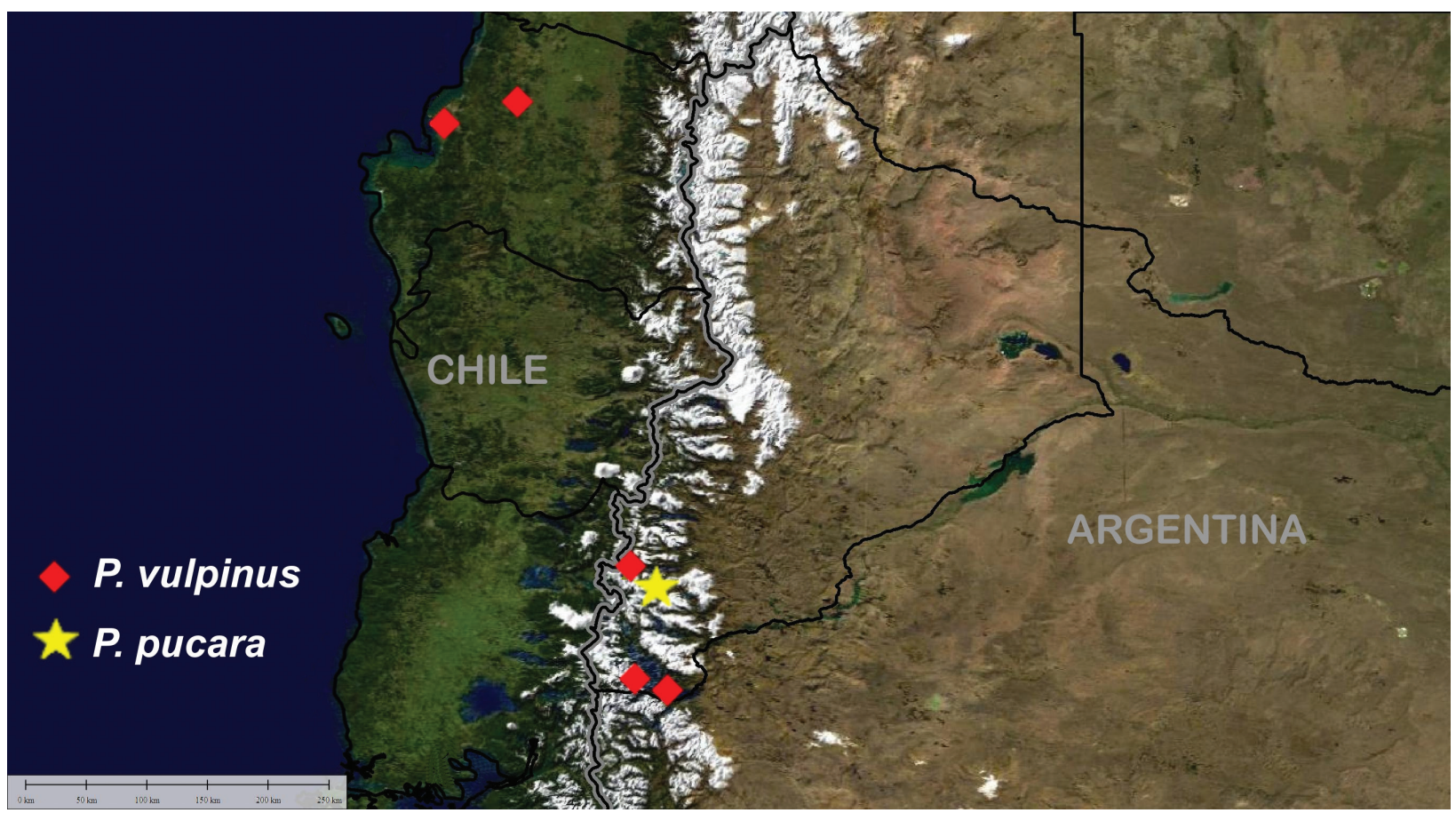

Fig. 11. Distribution map of Phrixotricus pucara sp. nov. and P. vulpinus (Karsch, 1880). 
of Los Lagos, Isla Victoria, XII.1941, Havrylenko leg. (MACN-Ar 5617); Õ, Argentina, Neuquén, La Unión, II.1959, J. Navas leg. (MACN-Ar 5613).

Distribution. Previously recorded for Chile, VIII Región del Biobío (Perafán \& Pérez-Miles, 2014). New records from Argentina, Neuquén province (Fig. 11).

Acknowledgements. Nelson Ferretti is a researcher at Consejo Nacional de Investigaciones Científicas y Técnicas (CONICET). Special thanks to Cristina Scioscia and Cristian Grismado (MACN-Ar) for loaning the specimens. Thanks to Alda González (CEPAVE, CCT-CONICET, La Plata, Argentina) for their constant support. Thanks to Gabriel Pompozzi for helping with the pictures.

\section{REFERENCES}

Bertani, R. 2000. Male palpal bulbs and homologous features in Theraphosinae (Araneae, Theraphosidae). Journal of Arachnology 28:29-42.

Bond, J. E. 2012. Phylogenetic treatment and taxonomic revision of the trapdoor spider genus Aptostichus Simon (Araneae, Mygalomorphae, Euctenizidae). Zookeys 252:1-209.

Bonnet, P. 1958. Bibliographia araneorum. Toulouse 2:3027-4230.

Cooke, J. A. L.; Roth, V. D. \& Miller, F. H. 1972. The urticating hairs of theraphosid spiders. American Museum Novitates 2498:1-43.

Coyle, F. A. 1995. A revision of the funnel web mygalomorph spider subfamily Ischnothelinae (Araneae, Dipluridae). Bulletin of the American Museum of Natural History 226:1-133.

KARSCH, F. 1880. Arachnologische Blätter (Decas I). Zeitschrift für die gesammten Naturwissenschaft 53:373-409.
LEgendRe, R. \& CALDERón-GonZÁLeZ, R. 1984. Liste systématique des araignées mygalomorphes du Chili. Bulletin du Muséum National d'Histoire Naturelle, 4e serie, 6, section A, 4:1021-1065.

Perafán, C. \& Pérez-Miles, F. 2014. The Andean tarântulas Euathlus Ausserer, 1875, Paraphysa Simon, 1902 and Phrixotrichus Simon, 1889 (Araneae: Theraphosidae): phylogenetic analysis, genera redefinition and new species descriptions. Journal of Natural History 48:2389-2418.

Pérez-Miles, F.; Lucas, S. M.; da Silva JR, P. I. \& Bertani, R. 1996. Systematic revision and cladistic analysis of Theraphosinae (Araneae: Theraphosidae). Mygalomorph 1:33-68.

Petrunkevitch, A. 1925. Arachnida from Panama. Transactions of the Connecticut Academy of Arts and Science 27:51-248.

Porter, C. E. 1930. Los artrópodos de la obra de Molina. Revista Chilena de Historia Natural 34:161-163.

Schiapelli, R. D. \& Gerschman de Pikelin, B. S. 1963. Los géneros chilenos Phrixotrichus Simon, 1889 y Paraphysa Simon, 1892 (Theraphosidae, Araneae) en la Argentina. Nuevas citas de algunas arañas comunes a ambos países. Revista de la Sociedad Entomológica Argentina 26:103-108.

Schmidt, G. 1996a. Die Typusart von Phrixotrichus Simon, 1888 (Araneida: Theraphosidae: Theraphosinae). Arachnologische Magazine 4:14-18.

. 1996b. Grammostola ist kein Synonym von Phrixotrichus (Araneae: Theraphosidae). Arthropoda 4:67-70.

Simon, E. 1889. Etudes arachnologiques. 21e Mémoire. XXX. Descriptions de quelques arachnides du Chili et remarques synonymiques sur quelques unes des espèces décrites par Nicolet. Annales de la Société Entomologique de France 8:217-222.

STRAND, E. 1908. Diagnosen neuer aussereuropäischer Spinnen. Zoologischer Anzeiger 32:769-773. 